University of Nebraska - Lincoln

DigitalCommons@University of Nebraska - Lincoln

To Improve the Academy

Professional and Organizational Development Network in Higher Education

1996

Transforming Faculty into an Agile Workforce

Robert Dove

Dina Wills

Follow this and additional works at: https://digitalcommons.unl.edu/podimproveacad

Part of the Higher Education Administration Commons

Dove, Robert and Wills, Dina, "Transforming Faculty into an Agile Workforce" (1996). To Improve the Academy. 355.

https://digitalcommons.unl.edu/podimproveacad/355

This Article is brought to you for free and open access by the Professional and Organizational Development Network in Higher Education at DigitalCommons@University of Nebraska - Lincoln. It has been accepted for inclusion in To Improve the Academy by an authorized administrator of DigitalCommons@University of Nebraska - Lincoln. 
Dove, R. \& Wills, D. (1996). Transforming faculty into an agile workforce. In L. Richlin (Ed.), To Improve the Academy, Vol. 15 (pp. 195-207). Stillwater, OK: New Forums Press and the Professional and Organizational Development Network in Higher Education. Key words: Career Development, Faculty Attitudes, Faculty Development Roles, Faculty Role.

\section{Transforming Faculty into an Agile Workforce}

\section{Robert Dove}

Lyceum Group

\section{Dina Wills}

Lehigh University

Some institutions of higher education have begun to implement agile operational strategies as they work to take advantage of new technologies and respond to new demands made from their various constituencies. Key to the success of these agile strategies is the ability of the faculty to create an agile learning environment. This paper focuses on the role of the faculty developer in creating that agile environment. It presents concrete programming suggestions and a model for faculty developers to follow as they assume the role of helping faculty become agile.

Business leaders, legislators, parents, students, and even a growing number of academic administrators like Purdue's William Plater (1994), Lehigh University's Peter Likins (1995) and Georgia Tech's John White (1995), are telling us that our institutions of higher education must change drastically if they are going to be relevant in meeting the needs of the 21st century. Following the lead of United States industry, many schools are looking to the concept of agility to help them prepare for the demands of the future. 
In the first major work on the subject published by members of the Iacocca Institute, Goldman, Nagel, and Preiss (1995) define agility as "a comprehensive response to the challenges posed by a business environment dominated by change and uncertainty" (p. 3). They continue with the following specifics:

For a company, to be agile is to be capable of operating profitably in a competitive environment of continually and unpredictably, changing customer opportunities. For an individual, to be agile is to be capable of contributing to the bottom line of a company that is constantly reorganizing its human and technological resources in response to unpredictably changing customer opportunities. (pp. 3 \& 4)

Later, in the same text, the authors suggest that, "Agility is dynamic, context-specific, aggressively change-embracing, and growth-oriented" (p. 42).

The authors of this paper predict that just as businesses all over the country have worked to create agile workforces to increase their ability to respond to rapid changes in the marketplace, faculties of higher education institutions will also need to become more agile for the same reason. The authors suggest that the success or failure of this transformation will depend on trust in the working relationship between faculty and administrators: chairs, deans, and provosts. They believe that the faculty development office on a campus can and should play a major role in facilitating trust-building activities between faculty and administration, and in providing training for faculty to become more agile in their teaching techniques, their teaching possibilities, their research possibilities and their potential to contribute in additional ways to the institution and the community served by that institution.

Agility is not only potentially critical to the survival of institutions but critical for faculty members who may find the research on which their reputations are built suddenly becoming obsolete. Faculty also should be able to model agility for their students, who will be entering a business world that expects them to be agile. We can convince students of the value of agility best by allowing them to experience it in the classroom and in their interactions faculty and other school personnel in areas such as financial aid, student life, and placement. 
The creation of a more agile institution and the transformation of the faculty to agility requires careful planning and constant communication. The model that the authors recommend includes the following stages:

1. Faculty and administrators together defining "agility in education" and creating a vision of what that would mean for their institution, building mutual trust during the process.

2. Defining the role of the faculty development office in the trust building and training processes.

3. Designing a program to create an agile, mobile faculty.

4. Implementing and evaluating the program.

The model presented does not suggest that these are discrete elements, but rather overlapping considerations that must taken into account as a transformation program to agility is developed.

\section{Creating an Institutional Vision and Definition of Agility}

As colleges and universities move from a teaching-centered to a learning-centered model of education, both the traditional faculty/student relationship and the traditional faculty career may undergo changes. Agility begins with a vision for an educational institution, including administration and all the other systems that support the main purpose of a college or university: interaction of faculty and students for the purpose of learning. We will present a working definition of agile faculty and examine the role of a faculty development office in designing a program that will encourage faculty to become more agile. The authors intend that their suggestions will apply to faculty in large universities, small colleges, two-year and four-year institutions.

In education, being agile means that a faculty member is able to learn and practice different methods of teaching and is able to work with others effectively, in both teaching and research. At one author's research institution, six senior faculty and administrators were interviewed in an effort to translate "agility language" from business to the academic setting. Interviewees included the president of the university, the director of a six-college consortium, and four faculty in 
philosophy, engineering and education. In interviews lasting two to three hours, these people talked about their perceptions of how the concept of agility would effect teaching methods, student learning, the traditional perception of faculty as individual researchers and solitary teachers, and other aspects of the 20th century paradigm of an institution of higher learning.

The following hallmarks were developed from interviews, as the author traced common themes that recurred in the six interviews:

1. Guide students in team-based learning.

2. Practice cross-disciplinary teaching.

3. Take into account different student learning styles when planning assignments, projects, papers, and tests.

4. Encourage critical and creative thinking rather than memorization and the solving of problems with pre-determined answers.

5. Design and practice creative uses of computer technology.

6. Model and teach good interpersonal skills.

7. Continue to search for ways to effectively measure the results of education.

Agile faculty are able to work in cross-disciplinary teams, who can see students as individuals who must be encouraged to think critically and connect concepts from different disciplines, and help students select and interpret ideas from the vast universe of information that is available in print and electronic form. These faculty also feel responsible for teaching students the interpersonal and team skills they will need as workers in an agile work environment.

For faculty, agility also involves an understanding of technology. This encompasses knowing how technology currently is used in particular disciplines, and staying aware of what direction it is going, both in the disciplines and in general. For example, classes can now be taught at Lehigh University in a classroom linked interactively (audio and video) with several other colleges. In the same interactive classroom, a person was interviewed recently by interactive video for a position in Australia. Agile faculty need to know how technology can improve the quality of their teaching and their research and how it will change their personal work lives.

Teamwork is also important to agility in education. For example, the faculty at a private technical school where one of the authors was 
employed worked in teams to take students through their course work and on to jobs. All members of each team were expected to teach a variety of courses within the curriculum, serve as counselors and advisors to the group of students assigned to their team, contact employers and help to get job interviews for their students upon graduation, research current job requirements revise courses to meet the current demands of business, and accompany admissions personnel on school visits. Using this system, a team could take a group of students through to graduation even if one of its faculty members were not available.

\section{Creating a Faculty/Administration Partnership}

It is a function of administration, in cooperation with faculty, staff, and students, to create a vision for an educational institution and then to create a vision of an agile, flexible faculty who will function within that system. No one faculty member can be expected to fill all possible faculty roles, but each person should be able to fill several roles, and to be proactive in searching for ways in which to serve the university's vision. We suggest three essential actions to support a vision of agile faculty:

1. Each faculty member should work with an administrator (department chair or dean) to create a job description that would match the strengths and career aspirations of the individual professor to the needs of the institution. In order to implement this, a high level of trust would need to exist. One way to build such trust is genuine cooperation between faculty and administration in the creation of a vision for the university or college.

2. The institution must identify workable reward systems that will promote faculty agility in both teaching and research.

3. The institution should maintain an office of faculty development, responsible for the improvement of instruction at the institution. This unit may also be responsible for other activities such as the management of technology, research grants, etc., but most importantly, it should support teaching in all the aspects mentioned above.

Our first suggestion for supporting the vision is done now, to some 
degree, by untenured faculty with their department chairs. Tenured faculty often have no performance reviews or career discussions with either chairs or deans. We suggest that this practice should be an important and on-going process for tenured and untenured alike. The traditional academic model produces faculty who work toward tenure, receive it, and spend their academic careers teaching the specialty in which they received their terminal degree. At the same time, they also do research, publish, serve as academic advisors and mentors for students, and are members of faculty committees. The emphasis is on becoming an individual scholar-teacher and holding students to identical standards in course work. Rarely does anyone discuss with faculty how their professional work fits into an institution-wide vision that will encourage faculty and students to learn together.

In contrast, agile scholar-teachers could work with administrators to identify how their professional skills could contribute best to the university's mission. For instance, team-teaching with faculty from other disciplines could let students learn about a subject such as media influence on political choices from the points of view of journalism, government, communication, and several languages. The subject of urban growth could be examined in separate classes in sociology, government, communication, and civil engineering, as faculty teaching those classes worked together on presentation of material. Research efforts by teams of faculty could be encouraged in many disciplines, which is not always the case now. Faculty could be steered toward university committees in which they had both expertise and interest, with such assignments spread across the entire faculty, not concentrated on the overloaded faculty willing to take on such assignments. For this consultation to succeed, faculty would need to be assured that new and workable reward systems would be used by administration to recognize such efforts.

Faculty should be encouraged to try new approaches in the classroom. Whenever different teaching methods are tried, there are bound to be some failures as well as successes. Administrators must recognize that success on some traditional measures such as student evaluations and peer reviews may mean only that the faculty member is sticking to safe methods of teaching and research, and not risking possible failure inherent in change. 
Agility means taking another look at the idea that a faculty member should teach only in a narrow spectrum where is or her specialty lies; faculty should be encouraged to teach multiple courses within their own disciplines and in related disciplines, as well as team-teach across disciplines. Agility means that courses that have been intended to weed-out weak students-engineering, pre-med, accounting, for instance-need to be taught from the point of view that the professor is successful when most of the students learn the material, not when half of them flunk the course. Implementing this change means presenting the material using teaching methods that reach students with different styles of learning. It also means that administrators should recognize that if students learn the material, they may earn higher grades, which is not a sign of grade inflation, but of learning. Because agility means that faculty need to learn to use a variety of teaching methods, our third suggestion of an office of faculty development working toward the improvement of teaching, is essential on every campus.

\section{The Role of the Faculty Development Office}

A campus faculty development office typically serves both the faculty and the administration. Because of this unique status, it can play a key role in building trust between these two entities as well as encouraging faculty to try new methods of teaching, if these efforts are supported by the institution's reward system. The authors explored the role of the faculty developer in creating agile faculty in a session at the POD conference in 1995. Participants in our session generated a list of six actions for faculty developers who want to help faculty become agile:

1. Understand the concepts of agility and become agile themselves, adapting to new opportunities while understanding the traditional academic culture and how slowly it changes.

2. Promote dialogue among the faculty, and between the faculty and administration. This is the trust-building dimension of faculty development work, which leads to the next recommendation.

3. Help to create a shared vision of agility with the faculty and administration. 
4. Identify the workable reward systems that will promote the transformation to agility. This could be done by using members of teams in disciplines that already have used such methods successfully, if such teams exist, or by finding working examples in other institutional settings. The faculty developer can help to identify such reward systems and help both faculty and administration put these in place.

5. Provide training for faculty in the use of technology. In many universities and colleges, the faculty development office and the media center are one unit. Whatever the institutional structure, the faculty development office must assure that faculty know about all available technology on the campus, and have training in its use.

6. Help faculty and administration meet the challenge of improving student retention by sharing current literature and concepts, and helping to implement strategies to improve student retention.

In addition to this list, we believe that faculty developers need to help faculty understand and trust the vision and mission of their institution, as well as provide encouragement and support for change and for personal and professional growth of individual faculty members. We suggest additional actions to implement these ideas.

For instance, faculty developers may provide workshops on several specific agile practices. A workshop on team-teaching would help professors focus on how to be an effective partner or team member when teaching with someone else. Another workshop could introduce the idea of cross-training faculty through the use of interdisciplinary teams by using members of teams in disciplines that have used such methods successfully. Workshops on the many forms of cooperative learning need to be an on-going part of the faculty development program (Johnson, D.W., Johnson, R.T., \& Smith, K.A., 1991). Workshops that help faculty encourage critical and creative thinking in every discipline should also be held on a regular basis (Brookfield, $S$. D., 1987). Workshops in how to become effective distance-educators are urgently needed by faculty who are learning this skill on the job. Such workshops might cover the standard lecture that is telecast by satellite with audio-feedback from distance learners, teaching in an interactive media classroom, and other computer teaching aids. 
In addition to workshops, faculty developers can make agile faculty well-known on their own campuses with press releases that appear in campus newsletters and alumni magazines, highlighting how their agile teaching methods influence their students and benefit the institution. Faculty may be encouraged to become "partners in learning," using one of the several existing systems to work with each other to assess their own teaching effectiveness (Centra, 1993).

Finally, faculty developers could spread the idea that fair treatment for students may not mean that everyone is treated alike, but could instead mean that all students have time to accomplish learning in their own ways. In a talk on "Agility in Education," Roger Nagel, director of Lehigh University's Iacocca Institute, noted that faculty often spend time helping students bend the university's rules to put together an interdisciplinary major and still graduate with the prescribed number of credit hours and requirements. Nagel said "There might be a better way than insisting on all those rules that are supposed to make life fair for all students, but actually become obstacles for students to maneuver around" (1995). This idea can also be used in the classroom, where student contracts for grades and other methods can encourage student initiative, while considering students' individual learning goals.

\section{Designing a Program to Create an Agile Faculty}

Besides support for individual faculty members as teachers, the faculty development office should play a major role in working with faculty and administration to design an institution-wide program to support an agile faculty. The design of such a program should include agreement on what roles need to be filled by faculty at a given institution; agreement on which roles are essential for all faculty to fill, and which can be accomplished by those who are best suited to them, and a procedure for an individual faculty member to work with a department head or dean on an individual program of personal and professional growth.

The three traditional areas of teaching, research, and service need redefinition for an agile faculty. Teaching may now include items that have been considered service, such as academic advising. We have 
grouped the following suggestions for faculty roles into four categories: teaching, research, academic governance, and university community.

Teaching roles could include teaching (individually or with team partners) several courses in one's primary discipline, using whatever teaching methods are appropriate to the subject matter and the needs of the students; team-teaching courses in one's primary discipline; team-teaching courses with faculty in other disciplines; advising students about their academic careers and their post-academic careers, which means working with the university's career services and with potential employers; learning and making use of the appropriate technology for teaching, and to stay current with expanding uses of technology, and teaching a certain number of credit hours each academic year.

Research roles could include doing research in one's area of interest; publishing in appropriate media, which includes electronic media as well as print media, and performance for those in the performing arts; sharing one's research with colleagues and with students, which may include working on teams with colleagues and students on research projects, and doing research on classroom teaching and publishing in appropriate educational journals.

Academic governance roles could include serving on departmental, college, and university committees that deal with such matters as curricula and the uses of technology, restructuring of academic units, and academic policy, and any other matters appropriate for faculty advice and consent. Each professor should serve on a reasonable number of such committees, sharing the academic governance equally among the faculty.

University community roles could include mentoring new faculty and teaching assistants; mentoring and coaching students; serving on interdisciplinary, inter-unit institutional teams that work on university-wide issues; assisting the admissions office in recruiting prospective students; meeting with prospective students and their parents; keeping in touch with graduates, and providing local community service. 


\section{Implementation and Evaluation}

When a faculty member has contracted with the department and dean for a number of these roles, there should also be agreement between faculty and administration about how progress should be evaluated, both for untenured and tenured faculty. The administration's obligation in the implementation of this program is to provide clear expectations and find fair methods of measuring progress. Department chairs working with untenured faculty usually find measurement of research progress easier than measurement of teaching or advising students. An additional role of the office of faculty development could be to get the faculty and the administration to agree on what measures should be used to gauge effective teaching.

Whatever faculty roles are agreed on as necessary at a given institution, the program design for agility must include an institutional commitment to provide opportunities for faculty to acquire the necessary skills to function effectively in those roles. The faculty development office should take responsibility for providing those opportunities. The faculty development office could also provide career path planning that includes interdisciplinary course development options, portfolio advice, and professional growth support.

Evaluation of faculty progress in successfully filling chosen roles should not be done by the office of faculty development. It is important to differentiate between a feedback and support process, done by faculty developers, and the evaluation process done by department chairs, faculty colleagues, and deans. However, faculty development personnel should have input into the decisions concerning the evaluation process and the instruments to be used in that process.

\section{Summary}

Many institutions of higher education are looking to agile operational strategies as a way to meet current and future challenges from their many constituencies and their competitors. They are also looking to agility as a way to cope with the rapid pace of change in technology, the educational environment, and society at large.

Key to the ability of educational institutions to become more agile is the ability of faculty to adopt new roles and to become agile 
themselves. The faculty development professional should play an essential role in this transformation of the faculty. Uniquely positioned to work with faculty and administration, the faculty developer must redefine his or her role to help the institution effectively achieve the capability to respond to unpredictable and continuous change.

The model and activities presented by the authors suggest that a holistic approach will produce the best results. They also suggest that a faculty-administration partnership is essential for success in such a drastic transformation of how most institutions currently function.

\section{References}

Brookfield, S.D. (1987). Developing critical thinkers: Challenging adults to explore alternative ways of thinking and acting. San Francisco: Jossey-Bass.

Centra, J. A. (1993) Reflective faculty evaluation: Enhancing teaching and determining faculty effectiveness. San Francisco: Jossey-Bass.

Goldman, S. L., Nagel, R. N., \& Preiss, K. (1995). Agile competitors and virtual organizations. New York: Van Nostrand Reinhold.

Johnson, D. W., Johnson, R. T., \& Smith, K. A. (1991). Active learning: Cooperation in the college classroom. Edina, MN: Interaction Book Company.

Likens, P. (1995, March). Opening plenary session comments at the 4th Annual Conference of the Agility Forum, Atlanta, GA.

Nagel, R. (1995). Agility in Education. Comments at the 4th Annual Conference of the Agility Forum, Atlanta, GA.

Plater, W. (1994, October). Future work: Faculty time in the 21st century. Keynote speech presented at the annual meeting of the Professional and Organizational Development Network, Portland, OR.

White, J.A. (1995, March). Luncheon comments at the 4th Annual Conference of the Agility Forum, Atlanta, GA.

Contact:

Robert Dove

Lyceum Group

29 Trembley Drive

Bethlehem, PA 18015 USA

(610) 758-3638

(610) 758-6198 FAX

dw03@lehigh.edu

Bob Dove has more than 20 years of consulting experience in the field of faculty development. He also served for 15 years as the Academic Dean for three different 
associate-degree-granting institutions. He recently spent two years as the Director of the Faculty Support Center for a two-year technical institute. He is currently Vice President of the Lyceum Group, an organization that consults with schools and businesses.

Dina Wills has taught communication in the Department of Joumalism and Communication at Lehigh University for eleven of her 25 years as an instructor. She has also served as Lehigh University's Faculty Development Director since 1989. In addition to her work on agility in education, Wills also investigates gender and communication. Her work on gender and communication stems from over thirty years of teaching and activism. She was one of the founders of the women's studies program at the University of Oregon in the early 1970 s and was instrumental in the revitalization of Lehigh University's women's studies program. 